Chapter 13

\title{
Soybean Under Water Deficit: Physiological and Yield Responses
}

\author{
Gustavo M. Souza, Tiago A. Catuchi, \\ Suzana C. Bertolli and Rogerio P. Soratto \\ Additional information is available at the end of the chapter \\ http://dx.doi.org/10.5772/54269
}

\section{Introduction}

The worldwide importance of soybean and the main limitations to crop yields

Because of its potential for large-scale production, soybean (Glycine max (L.) Merrill) has excelled in the world agricultural economy as a major oilseed crop. At present, soybeans are grown primarily for oil extraction and for use as a high protein meal for animal feed (Singh \& Shivakumar, 2010). According to Li-Juan \& Ru-Zhen (2010), soybean has a protein content of approximately $40 \%$ and an oil content of approximately $20 \%$. In 2010 , the area planted with soybeans worldwide was 102.4 million hectares, with total production of 261.6 million tons in the same year (Faoestat, 2012). This crop is currently being produced around the world, including in much of North America, South America and Asia. The U.S. and Brazil are the world's largest producers and exporters of soybean (Kumudini, 2010).

According to Mutei (2011), with the increasing world population, which is expected to reach nine billion people by 2050, the worldwide production of food should increase by $70 \%$ to ensure food security, which should be achieved through growth in productivity, rather than simply through the expansion of cultivation areas. Câmara \& Heiffing (2000) indicate that to obtain increases in soybean yields, it is necessary to understand the interaction between cultivars and the production environment. Based on these factors, crop management can be adjusted to achieve proper development of plants in each production environment. Soybean is very responsive to environmental conditions, and the main climatic factors affecting its crop yields include the photoperiod, which influences the availability of full light, temperature and water availability (Mundstock \& Thomas, 2005). 
Although the effects of various environmental factors interfere with the performance of crops, water restriction is the main limiting environmental factor that contributes to the failure to obtain maximum soybean yields (Casagrande et al, 2001), influencing the use of other environmental resources. According to Confalone \& Navarro Dujmovich (1999), the efficiency of the use of solar radiation by soybean remains relatively constant at different development stages. When there is moderate water stress, soybean tends to maximize the efficiency of radiation utilization and reduce the efficiency of the interception of photosynthetically active radiation, while under severe water deficits, there is a reduction of the efficiency of radiation utilization.

Lisar et al. (2012) report that the impacts of water stress in crop plants can reduce productivity by $50 \%$ in various parts of the world. Under stress conditions, the plants present a series of changes in their morphology, physiology and biochemistry, negatively affecting their growth and productivity. According to Gerten \& Rost (2010), two-thirds of world food production through cultivation occurs under water stress. In this context and because of the prospect of global climate change, most crops will be exposed to negative impacts caused by drought.

\section{Effects of water deficits on soybean: Crop yields and general responses}

Water participates in nearly all physiological and biochemical processes in plants, comprising approximately $90 \%$ of their mass (Farias et al, 2007). It is responsible for the thermal regulation of the plant, acting both to maintain the cooling and heat distribution and to promote mechanical support of the plant (Taiz \& Zeiger, 2009). It also functions as a solvent, through which gases, minerals and other solutes enter cells and move within plants (Nepomuceno et al, 1994).

The need for water in soybean increases with plant development, peaking during the flowering-grain filling stages (7-8 $\left.\mathrm{mm} \mathrm{day}^{-1}\right)$ and decreasing thereafter. The total water requirement for maximum productivity varies between 450 and $800 \mathrm{~mm}$, depending on weather conditions, crop management practices and cycle timing (Embrapa, 2011, Farias et al, 2007). The loss of productivity under water deficit conditions depends on the soybean phenological stage, duration and intensity of water shortages (Doss \& Thurlow, 1974). Kron et al. (2008) evaluated the responses of soybean to water stress induced in different phases in the plants and concluded that plants subjected to water stress during the V4 stage showed an increased tolerance to water shortages in later stages. This stage was considered to represent a "developmental window" in soybean, characterized as a specific period during plant development when environmental disturbances can be embodied, thereby improving subsequent plant resistance to environmental changes (Kron et al., 2008).

Desclaux et al. (2000) evaluated the effects of water stress at various stages of development in soybean plants and found the average length of the internodes to be the most sensitive feature to drought imposed during the vegetative stages (V4) and flowering (R1-R3), and a reduction in plant height was associated with water stress induced in the V4 stage. The 
number of pods per unit of shoot dry matter was significantly affected by water deficits in the reproductive stages (R3-R5). When stress occurred during grain filling (R5), the characteristics of the plant that were most affected were the number of grains per pod and the grain weight. Rosolem (2005) notes that the water demand of soybean is highest at the initiation of flowering, but a water deficit from pod initiation (R3) until 50\% yellow leaves (R7) is the most critical stage for productivity. In a study performed by the same author correlating rainfall with grain yields, it was found that when water restriction occurred between flowering and the emergence of pods, the grain yield of soybean was $1,275 \mathrm{~kg} \mathrm{ha}^{-1}$, but under no water limitation at this stage, there may be an increase in productivity of $3.8 \mathrm{~kg} \mathrm{ha}^{-1}$ for each $\mathrm{mm}$ of rain. When water restriction occurred during grain filling, the yield was $878 \mathrm{~kg} \mathrm{ha}^{-1}$, and for each mm of rain, there was an increase in productivity of $13 \mathrm{~kg} \mathrm{ha}^{-1}$, indicating the greater susceptibility of the soybean to water stress during grain filling, although the highest water demand in the crop occurred at the beginning of flowering (Desclaux et al., 2000). These results are in agreement with those of Nogueira\& Nagai (1988). However, other studies observed that seed filling is not the most drought prone period of soybean development. When the water deficit starts during R1 (early flowering) and R4 growth stage, the seed yield may be significantly reduced (Eck et al., 1987, Brown et al., 1985, Hoogenboom et al., 1987) compared to R6-R7 growth stage.

According to Santos \& Carlesso (1998), the most prominent responses of plants to water deficits in terms of morphological processes are decreases in leaf area and acceleration of the senescence and abscission of leaves. Catuchi et al. (2011) studied the conventional cultivar CD 220 and the transgenic cultivar CD 226RR under water deficits induced at the V4 stage, and they observed a reduction of approximately $40 \%$ of leaf area per plant compared to control plants and decreasing shoot dry mass of approximately $50 \%$ for both cultivars. Akinci \& Losel (2012) reported that water stress drastically decreased root elongation and the expansion of leaf area in soybean, though these two processes were not equally affected because leaf expansion is usually reduced by a greater proportion than root growth, and carbon partitioning shifts to increase the root/shoot ratio. Catuchi et al. (2012) studied the responses of biomass and leaf area in plants of two soybean cultivars, BR 48 and EMBRAPA 16, which are considered tolerant and susceptible to water restriction, respectively, grown under water deficits. The authors observed a reduction of all traits in both cultivars due to a water deficit imposed in the reproductive stage of culture, with the exception of root dry mass in Embrapa 48, which remained unchanged, even under conditions of water restriction (Table 1). This phenomenon may occur because drought can promote the expansion of the root system to reach additional deeper moisture zones in the soil profile, a process that begins gradually after drying of the soil surface (Santos \& Carlesso, 1998). The reduction of the other biomass parameters under conditions of water deficits is related to decreased photosynthetic rates, and biomass accumulation and translocation to grain are consequently impaired (Neumaier et al., 2000).

One of the most important processes of nitrogen nutrition of soybean, which results in improvements of productivity and profitability of the crop, is the symbiotic nitrogen fixation. Nevertheless, this process is negatively influenced by low moisture (Purcell et al, 2004; Pur- 
cell \& Specht, 2004). Decreased nitrogen fixation starts when water potential of root nodules starts falling below -0.2 to -0.4 MPa (Pankhurst \& Sprent, 1975). According to the Purcell et al. (2000), the water deficit promotes the accumulation of products of $\mathrm{N}_{2}$ fixation (ureides) in the shoot of soybean plant, causing a feedback reduction in fixation of $\mathrm{N}_{2}$. Thus, the authors report that proper nutrition with manganese $\left(\mathrm{Mn}^{+2}\right)$ promotes the breaking of ureides and extends $\mathrm{N}_{2}$ fixation in plants under water deficit. Furthermore, soybean plants that produce larger nodules are less susceptible to reduction of nitrogen fixation in water deficit conditions (King \& Purcell, 2001).

\begin{tabular}{ccccc}
\hline \multirow{2}{*}{ Attributes } & \multicolumn{2}{c}{ BR-16 } & \multicolumn{2}{c}{ Embrapa 48 } \\
\cline { 2 - 5 } & Control & Water deficits & Control & Water deficits \\
\hline$S M(g)$ & $26.3^{\mathrm{A}(1)}$ & $13.9^{\mathrm{B}}$ & $23.9^{\mathrm{A}}$ & $11.4^{\mathrm{B}}$ \\
\hline $\mathrm{SD}_{\mathrm{m}}(\mathrm{g})$ & $57.1^{\mathrm{A}}$ & $29.1^{\mathrm{B}}$ & $51.8^{\mathrm{A}}$ & $25.2^{\mathrm{B}}$ \\
\hline $\mathrm{RD}_{\mathrm{m}}(\mathrm{g})$ & $8.3^{\mathrm{A}}$ & $5.1^{\mathrm{B}}$ & $5.6^{\mathrm{A}}$ & $4.6^{\mathrm{A}}$ \\
\hline $\mathrm{OD}_{\mathrm{m}}(\mathrm{g})$ & $65.4^{\mathrm{A}}$ & $34.3^{\mathrm{B}}$ & $57.4^{\mathrm{A}}$ & $29.8^{\mathrm{B}}$ \\
\hline $\mathrm{A}_{1}\left(\mathrm{~cm}^{2}\right)$ & $1637.7^{\mathrm{A}}$ & $756.7^{\mathrm{B}}$ & $1356.1^{\mathrm{A}}$ & $724.3^{\mathrm{B}}$ \\
\hline
\end{tabular}

${ }^{(1)}$ Means followed by the same letters between the levels of water reposition in each cultivar not differ by Tukey test $(P=5 \%)$.

Table 1. Seed mass per plant $(S M)$, shoot dry mass $\left(S D_{m}\right)$, root dry mass $\left(R D_{m}\right)$, overall dry mass $\left(O D_{m}\right)$ and overall area leaf $\left(A_{1}\right)$ of BR-16 and Embrapa 48 soybean cultivars with $100 \%$ and $40 \%$ water reposition (adapted from Catuchi et al., 2012)

Water restriction may be caused by several factors in plants, with the principal cause being an absence or an irregular distribution of rainfall during the crop cycle (Gopefert et al., 1993). In recent years, due to global climate change, climate stability, which allows the cultivation of crops to be planned, has been more limited. For plants to withstand periods of water restriction, they should be able to maintain their water status at normal turgor pressure during the hottest hours of the day, when the water vapor atmospheric demand is greater. This requires that the plant have a well-developed root system allowing it to reach water in deeper layers in the soil profile (Farias et al, 2007). In some cases, the limited extent of the root system reduces the water supply to plants. These responses are typical of soils containing toxic aluminum $\left(\mathrm{Al}^{3+}\right)$ combined with low rainfall during the crop cycle. The presence of $\mathrm{Al}^{3+}$ could limit the development of the root system due to inhibition of DNA synthesis and cell division, limiting the elongation of the roots and thus, the absorption of water from the deeper layers of soil. It also causes changes in nutrient uptake and in the overall nutritional balance of plants (Machado, 1997). Mascarenhas et al. (1984) observed a reduction of primary roots of plants of two cultivars of soybeans due to increased levels of $\mathrm{Al}^{3+}$ in a nutrient solution. Nolla et al. (2007) assessed the root development of soybean seedlings grown in solution with various concentrations of $\mathrm{Al}^{3+}\left(0.0,0.30,0.60\right.$, and $\left.1.20 \mathrm{mmol} \mathrm{L}^{-1} \mathrm{Al}\right)$ and ob- 
served a significant reduction of the root dry mass due to the increased concentration of $\mathrm{Al}^{3+}$ at $\mathrm{pH}=4$ (Figure 1).

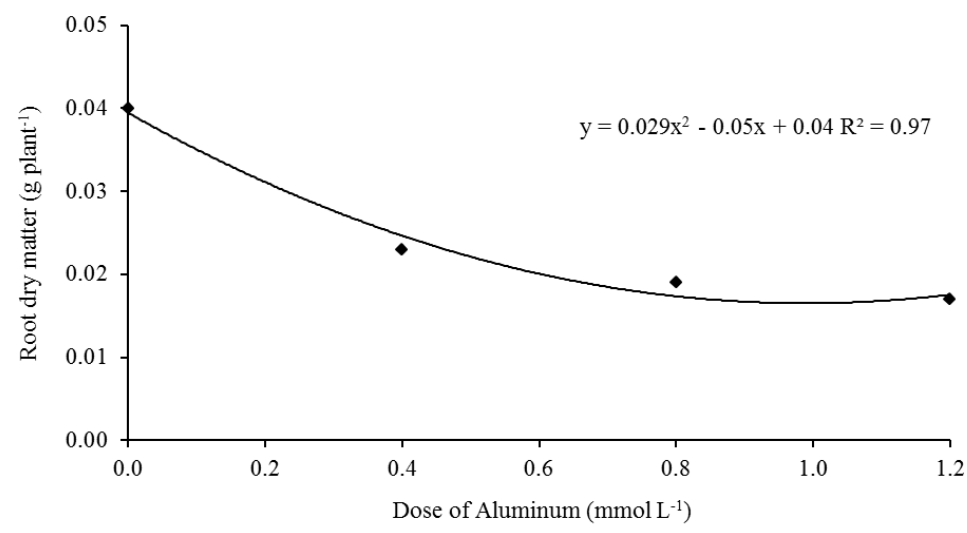

Figure 1. Root dry mass of soybean seedlings grown under different concentration of aluminum. (adapted from Nolla et al, 2007).

Moreover, soil compaction caused by the pressure of agricultural implements on farms is another limiting factor for deep root development. In the work carried out by Cardoso et al. (2006), there was a significant correlation found between the root volume of two soybean cultivars and the resistance to penetration (RP), with the root volume decreasing linearly in both cultivars associated with increases in RP. According to Beutler \& Centurion (2003), the growth of the soybean root system is limited when the RP is greater than $2 \mathrm{MPa}$. Beutler et al. (2006) note that soybean yield decreases in RPvalues from 2.24 to $2.97 \mathrm{MPa}$.

In this sense, the use of implements that do not cause soil compression and cultivation techniques such as "no-tillage systems" (NTS) that result in better soil physics, promoting better root development at depth, are extremely important to avoid loss of productivity due to water restriction. Furthermore,some agricultural practices, such as lime and gypsum application may promote the correction of the soil profile (Santos et al, 2010).

According to Franchini et al. (2009), under NTS, the maintenance of the soil covering reduces evaporative water loss due to the formation of a physical barrier and reduces the temperature of the soil and runoff because of the increased capacity of water infiltration associated with protection of the surface of the soil against the impact of raindrops, thus preventing crusting. Similarly, increasing the percentage of soil organic matter (SOM), which is associated with a reduced intensity of soil cultivation, substantially improves the soil structure, which favors the development of soybean roots and thus increases the size of the water reservoir available. In addition, improvements in the soil structure provided by NTS increase infiltration and the water retention of the soil, thus favoring the upward flow of water from deeper layers to upper layers, where the majority of the soybean root system 
develops. The effects of SOM are connected with the hygroscopicity and high specific surface area of this type of material, which promotes increased water retention (Braida et al, 2011). In a long-term study, Franchini et al. (2009) reported that during the first four seasons after the adoption of aNTS, the soybean yield was similar or slightly lower than that obtained under conventional tillage (CT). However, from the fifth year onward, when the system had matured and consolidated, the soybean yield was higher under the NTS than the CT (Figure 2).

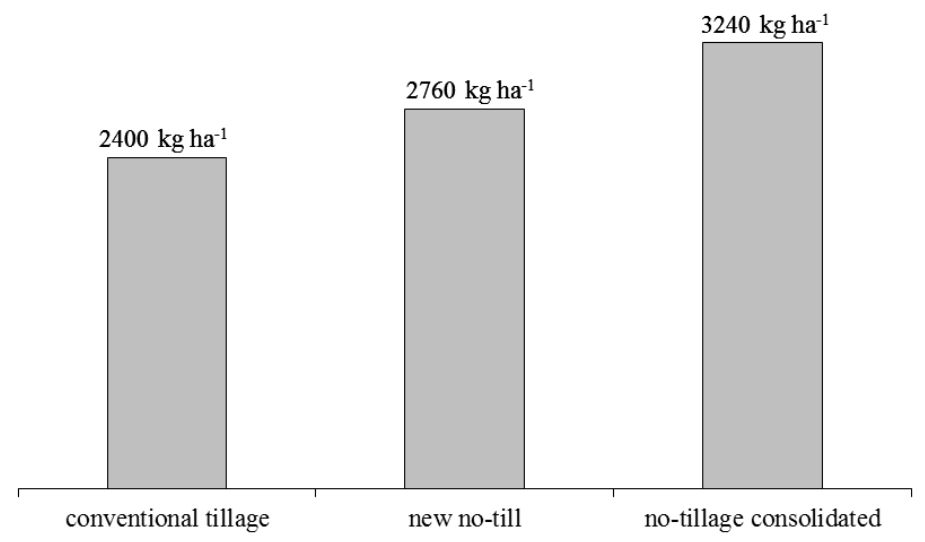

Figure 2. Soybean yield in different management systems: conventional tillage (13 years); new no-tillage ( 3 years) and no-tillage consolidated (13 years), (adapted from Franchini et al., 2009).

Sowing according to agroclimatic zoning for each agricultural environment is another strategy to avoid productivity losses due to water restriction. The cultivar must be adapted to the region considering the climate and soil type that determine water retention. In regions with higher occurrences of drought, it is essential to cultivate material that is more tolerant to water restriction. Thus, when the chemical and physical conditions of soil are suitable, allowing good root development at depth, and the cultivar and sowing time are selected to minimize the effects of water restriction, it is possible to obtain a high productivity soybean grain yield.

Overall, to achieve productivity under any conditions, it is essential that the process of photosynthesis, which is responsible for all carbon assimilated for the production of biomass, has a minimum efficiency. Under water deficit conditions during the soybean cycle, photosynthesis is one of the main physiological processes affected.

\section{Influence of water deficiency on plant physiology: An overview}

Drought stress is a factor that occurs when little water is available in an appropriate thermodynamic state. The term "dry" indicates a period without appreciable precipitation during 
which the water content in the soil is reduced (Larcher, 2000). This situation can be exacerbated when atmospheric conditions cause continuous water loss via transpiration or evaporation (Jaleel et al., 2009).

Depending on environmental conditions, different levels of water loss can occur. While water deficiency is a state caused by a moderate loss of water, which causes stomatal closure and reduction of gas exchange (Jaleel et al., 2009), desiccation is caused by much more extensive losses of water, which can potentially lead to major disruption of cellular structure and metabolism and eventually to an interruption of enzyme-catalyzed reactions (Smirnoff, 1993, Jaleel et al. 2009).According to Jaleel et al. (2009), water stress is characterized by reductions in water content and leaf water potential and loss of cellular turgor, which decreases stomatal conductance and cellular expansion, consequently constraining plant growth. Severe water stress can result in impairment of photosynthesis, metabolic disorders and ultimately death of the plant. In addition, other factors, such as high temperatures, soil salinity, pathogen attack and mechanical damage, may also contribute to differences in the amount of water in plants by interfering with their development and reducing their productivity (Larcher, 2000).

Once successful stand establishment is achieved, one of the most sensitive physiological processes to drought stress is reduced cell expansion resulting from decreased turgor pressure (Raper \& Kramer, 1987). As leaf water potential falls, cell and leaf expansion are affected before photosynthesis. Bunce (1977) reported a linear relationship between soybean leaf elongation rate and turgor pressure. Decreasing leaf water potential to $-0.80 \mathrm{MPa}$ reduced leaf elongation rate by $40 \%$ relative to greater values of water potential. Consequently, leaf area and plant dry matter were reduced $60 \%$ and $65 \%$, respectively. These results were subsequently confirmed in field experiments (Muchow et al., 1986). Thus, occurrence of water deficit during vegetative growth (emergence to R5) can reduce the leaf area indices (LAI) and the interceptation of photosynthetically active radiation by the total leaf area to levels insufficient for optimal crop growth rate (CGR) and yield. The effects of water stress on photosynthetic rates of soybean leaves are readily detectable at leaf water potentials about -1.0 to -1.2 MPa (Raper\& Kramer, 1987). The rate starts declining more rapidly as water potential falls below -1.8MPa. Plants suffering this level of drought would have greater reductions of CGR and yield because not only would LAI be reduced, but the net assimilation rate (photosynthetic rate per unit LAI) would also be reduced. Drought stress effects on photosynthesis become irreversible once water potential falls below -1.6 MPa.

The stress induced by water deficits in plants depends on the conditions provided by the environment, varying according to the intensity and duration of water deficits, the rate of water deficit induction and the stage of plant development when drought occurs (Pinheiro \& Chaves, 2011, Bertolli et al., 2012). Moreover, these factors can strongly influence the process of mitigation associated with acclimation to conditions after water shortages (Chaves et al., 2009). Acclimation responses in plants under water stress generally include responses related to growth inhibition or leaf shedding, reducing the water consumption by these tissues and contributing to the maintenance of water balance and the assimilation of carbon (Chaves et al., 2009, Pinheiro \& Chaves, 2011). Osmoregulatory el- 
ements produced in response to slow dehydration also have the function of maintaining metabolic activity, improving cell osmotic adjustment (Pang et al., 2011). The increase in sugar levels during leaf dehydration appears to be the result of coordinated regulation of the synthesis and translocation of sucrose, contributing to osmotic adjustment and enabling the maintenance of turgor in meristematic regions. These responses may eventually lead to restoration of cellular homeostasis, thereby increasing plant survival under stress (Chaves, 1991, Chaves et al., 2009).

A central question in plant biology is related to the problem of the optimization of $\mathrm{CO}_{2}$ fixation in environments with limited water. In environments where there is water restriction caused by a lack of water from the soil or by a high atmospheric water demand plants tend to close their stomata to conserve water via reducing transpiration losses, which may limit the $\mathrm{CO}_{2}$ intake into the leaf for photosynthesis (Kaizer, 1987, Flexas et al., 2009, Pinheiro \& Chaves, 2011). Control of the entry of $\mathrm{CO}_{2}$ and water loss is performed by continuously setting the opening of the stomata distributed across the leaves. This dynamic of opening and closing of stomata is heterogeneous and can be particularly enhanced under conditions of water stress, causing the patchy stomatal conductance phenomenon to occur (Mott \& Buckley, 1998, Flexas et al., 2009).

The response of photosynthesis under water stress has been the focus of study and debate for decades, particularly with respect to what the most limiting factors for photosynthesis are (Lawlor \& Cornic, 2002, Lawlor \& Tezara, 2009, Flexas et al., 2009). However, there is still some controversy regarding the importance of the main physiological parameters and the time period over which they limit photosynthesis (Pinheiro \& Chaves, 2011).

The decrease in $\mathrm{CO}_{2}$ diffusion from the atmosphere to the carboxylation site of Rubisco (ribulosebiphosphate carboxylase/oxygenase) is generally considered to be the main cause of reduced photosynthesis under conditions of mild and moderate water deficits (Grassi \& Magnani, 2005, Chaves et al., 2003, 2009, Pinheiro \& Chaves, 2011). Greater resistance to the diffusion of $\mathrm{CO}_{2}$ may be caused by both stomatal limitation and by lower conductance in the mesophyll (Flexas et al., 2009). The stomata act in regulating the entry of $\mathrm{CO}_{2}$ (an essential substrate for photosynthesis) into the leaves and the loss of water vapor to the atmosphere via transpiration. The control of gas exchange between the leaf and the atmosphere through the stomata is essential for the maintenance of photosynthetic activity and tissue hydration (Reynolds-Henne, et al. 2010, Aasamaa \& Sõber, 2011). When the decrease in stomatal conductance is combined with high light levels, the leaves are subjected to an excessive amount of incident energy in relation to the amount of intercellular $\mathrm{CO}_{2}$ available for photosynthesis, and the rate of reductant energy production can therefore overlap with the rate of its consumption by the Calvin cycle. Under these circumstances, down-regulation of photosynthesis or even photoinhibition can become a powerful defense mechanism for plants (Pinheiro \& Chaves, 2011, Sanda et al. 2011). This protection can be achieved via thermal dissipation occurring in the light harvesting complex of the photochemical apparatus, involving the xanthophyll cycle (Demmig-Adams et al. 2006, Sarlikioti et al. 2010), and through alternative sinks for the excess energy, such as photorespiration (Lawlor \& Cornic, 2002, Miyake, 2010) or the Mehler reaction, now referred to as the water-water cycle 
(Miyake, 2010). Because there is dependence on the fixation of $\mathrm{CO}_{2}$ and photochemical efficiency (ATP generation and NADPH) and vice-versa (Miyake et al., 2009), any stress or situation that reduces the consumption of photochemical products through decreased carboxylation efficiency can generate excessive excitation energy (Baker et al., 2004, Sarlikioti et al., 2010). When the non radioactive de-excitation energy (NPQ) is insufficient to address this excess energy, alternative electron sinks, such as the water-water cycle and photorespiration, are activated, which is crucial for maintaining photosynthetic activity (Miyake et al., 2009, 2010, Lawlor \& Tezara, 2009).

Part of the reduction of photosynthesis can be attributed to non-stomatal effects at the chloroplast level, and electron transport and photophosphorylation are the main targets of inhibition (Sanda et al., 2011). The reduction in ATP synthesis that is an initial response to water deficits can lead to reduction of the capacity for Ribulose-1,5-bisphosphate (RuBP) regeneration, reducing potential photosynthesis (Lawlor \& Tezara, 2009, Pinheiro \& Chaves, 2011). Furthermore, Rubisco activity may be impaired by Rubisco activase activity and the reduction of ATP. Lawlor \& Tezara (2009) claim that inhibitors such as RuBP analogues bind to the active site of Rubisco, decreasing its activity, especially when the concentration of RuBP is under saturated due to water deficiency. The regulation and restoration of Rubisco are mediated by Rubisco activase and require a high rate of ATP/ADP conversion. Thus, because phosphorylation is reduced under water stress, the activity of Rubisco is depressed (Parry et al., 2002).

In addition to solar energy, water availability and air temperature are elements that show seasonal variation (Rossato et al. 2009) and can affect photochemical activity. High temperatures may also affect photochemical activity directly through the inactivation of photosystem II and structural disorganization of the thylakoids or indirectly by the reduction of the activity of the Calvin cycle (Zhang \& Sharkey, 2009). Plants subjected to water deficits usually exhibit reduced transpiration and therefore show a low capacity for dissipation of latent heat, increasing the temperature of the leaves. This condition can decrease the fixation of $\mathrm{CO}_{2}$ because under increasing temperatures, Rubisco activity tends to be reduced (Kumar et al., 2009).

\subsection{Effects of water stress on photosynthesis in soybean plants}

Studies on the soybean crop have been focused on describing the impacts caused by the imposition of water stress on physiological parameters, particularly on photosynthesis in different genotypes (Desclaux \& Roumet, 1996, Kron et al., 2008, Firmano et al., 2009, Catuchi et al., 2011, Bertolli et al., 2012, Catuchi et al., 2012). In the cultivars 'New Tanbakuro' and 'Tamanisiki' (Ohashi et al. 2009), 'CD 202' and 'CD 226RR' (Catuchi et al., 2011), 'BR 16' and 'Embrapa 48' (Catuchi et al., 2012) and 'MG/BR-46' (Conquista) (Stolf-Moreira et al., 2011) and wildtype plants (Kao \& Tsai, 1998), it has been observed that the photosynthetic rate, stomatal conductance and transpiration were reduced by water deficits. Moreover, there was a reduction in the intercellular $\mathrm{CO}_{2}$ concentration (Ci) observed in the cultivars 'BR 16' (Catuchi et al., 2012) and 'Embrapa 48' and wildtype species. Additionally, in the cultivars 'New Tanbakuro' and 'Tamanisiki', Ci was altered slightly under 
early water stress treatments, while for the cultivars 'MG/BR-46' (Conquista) and 'BR 16' (Stolf-Moreira et al., 2011), Ci increased as the water deficit progressed, indicating different physiological responses for different soybean cultivars. Furthermore, an increase in the intrinsic efficiency of water use was observed when the cultivars 'CD 202', 'CD 226RR', BR 16 and EMBRAPA 48 were subject to episodes of water restriction (Catuchi et al., 2011 and 2012). According to Manavalan et al. (2009), this increase may indicate better control of water loss via transpiration, contributing to the productivity of soybean. However, it is important to take into account that the studies discussed herein used different methods of water stress induction, which could interfere with making more reliable and suitable comparisons among cultivars (Bertolli et al., 2012).

Reduction of net photosynthesis in soybean plants can be induced by both stomatal and non-stomatal factors (of both biochemical and photochemical origin). When a crop is subjected to a water deficit, the plants can reduce their stomatal conductance (gs), limiting the entry of $\mathrm{CO}_{2}$ into the substomatal chambers and thus reducing the diffusion of carbon to the site of carboxylation, resulting in significant decreases in carbon assimilation ( $\mathrm{Yu}$ et al., 2004). Furthermore, Flexas et al. (2006a) report that the effects of water stress on the initial activity of Rubisco may be reproduced by induction of stomatal closure, independent of the reduction in the relative water content in the leaves of soybean plants. Thus, we can expect a lower regulation of photochemical and biochemical processes when the availability of $\mathrm{CO}_{2}$ is the most limiting component for photosynthesis in plants under severe water stress (Flexas et al. 2006b).

Although Pankovic et al. (1999) report that the content of Rubisco in soybean leaves increases as plants acclimate to water stress, other authors have observed that under the imposition of water deficits in pine, tobacco and soybean, there is reduced transcription of the subunits of this enzyme (Pelloux et al., 2001, Kawaguchi, et al., 2003, Majumdar et al., 1991, respectively). Reduction of the Rubisco activity in soybean plants under drought stress can be induced by reducing the content of the enzyme itself and possibly through increases in strongly binding inhibitors, as reported by Flexas et al. (2006a). When stomatal closure occurs for a period of several days, another mechanism involving gene expression can operate, resulting in a decrease in the total amount of Rubisco and/or an increase in the content of inhibitors that bind strongly to this enzyme (Flexas et al., 2006a).

Moreover, when the availability of $\mathrm{CO}_{2}$ and biochemical activity are reduced due to water deficits, the excess reductants in the photochemical apparatus must be dissipated as heat or drained through alternative electron sinks (Miyake et al., 2009, 2010) to reduce photoinhibition and the production of reactive oxygen species (ROS). Studies have revealed that PSII of soybean plants is resistant to moderate water stress (Kirova et al., 2008), and the potential quantum efficiency of PSII $\left(F_{v} / F_{m}\right)$ and electron transport rate (ETR) are not altered by the imposition of water stress (Ohashi et al., 2006). Bertolli et al. (2012) reported that the decrease in the ETR was more sensitive than the decrease of $F_{v} /$ $\mathrm{F}_{\mathrm{m}}$ when the relative water content declined in soybean plants (cv. CD202), supporting the idea that the potential photochemical efficiency would not be readily affected by water deficiency. However, the reduction of the ETR could be due to a lower energy (ATP / 
NADPH) demand being required for carbon fixation metabolism under water deficit. Because the stomatal conductance was decreased as water deficiency progressed, the reduction of $\mathrm{CO}_{2}$ diffusion from the substomatic chamber to the active site of Rubisco may have influenced the efficiency of the Calvin cycle, which, in turn, may have reduced the consumption of ATP / NADPH from the photochemical apparatus, reducing the efficiency of the electron transport chain (Bertolli et al., 2012).

Depending on the intensity and duration of drought stress, metabolic limitations are frequently observed to be correlated with decreases in ATP, which reduces the capacity for RuBP turnover (Parry et al., 2002). This reduction in ATP synthesis is due to the decrease in electron transport and photophosphorylation caused by the reduction of the reactions associated with the chloroplast membranes (Catuchi et al., 2011). These membranes may suffer structural damage caused by decreasing the content of free water and ROS overproduction (Lawlor \& Cornic, 2002), reducing the efficiency of the photochemical apparatus. Kao \& Tsai (1998) also reported that the amount of quinone (QA) in the reduced state in a wild type soybean plant under water stress is greater than in plants irrigated under high light. The increase in the reduced state of QA is associated with the amount of inactivated and damaged D1 protein in the PSII reaction centers, indicating susceptibility of the photochemical apparatus to water deficits.

\section{Aspects of mineral nutrition in the relationship between water deficits and plant physiology}

Under water stress, plants develop various physiological and molecular mechanisms to maintain productivity. Among these mechanisms, Nepomuceno et al. (2001) highlight the activation of genes induced by drought to promote cell tolerance to dehydration and osmotic adjustment to maintain the water potential and turgor close to optimum levels. Additionally, to minimize the oxidative damage to cells generated by reactive oxygen species (ROS), plants develop antioxidant systems (Apel \& Hirt, 2004).

In addition to the internal mechanisms in plants, the negative effects of water stress can be minimized through a balanced supply of nutrients (Waraich et al., 2011). Among the nutrients classified as essential (Dechen \& Nachtigall, 2006), potassium (K), phosphorus (P) and calcium (Ca) are the most studied in relation to their roles in reducing the effects of water stress on the physiology of soybean (Waraich et al, 2011).

\subsection{Effects of potassium}

Potassium is considered to be the second most extracted element in soybean crops (Malavolta, 2006). From $1,000 \mathrm{~kg}$ of seeds produced by a soybean crop, $20 \mathrm{~kg}$ of $\mathrm{K}_{2} \mathrm{O}$ can be extracted (Mascarenhas, 2004). In this context, in some agricultural production systems, particularly tropical systems, $\mathrm{K}$ application is required to ensure soil productivity. More than 60 enzymes involved in cell metabolism are $\mathrm{K}$ dependent for normal activity because this nutrient 
is an important enzymatic activator (Prado, 2008). Moreover, $\mathrm{K}$ plays an important role in cell expansion, which involves the formation of a large central vacuole occupying $80 \%$ to $90 \%$ of cell volume.

Under water deficit conditions, stomatal conductance is reduced (Oliveira et al, 2005) consequently decreasing the intercellular $\mathrm{CO}_{2}$ concentration (Kaiser, 1987, Lawlor \& Tezara, 2009). Thus, the light energy used for the fixation of $\mathrm{CO}_{2}$ is diverted to $\mathrm{O}_{2}$, generating high accumulation of ROS in the chloroplast (Pitzschke et al, 2006). According to Cakmak (2005), when plants are grown under low $\mathrm{K}$ availability, the production of free radicals may be increased because the lack of this nutrient disturbs the opening and closing mechanism of stomata, causing a reduction of photosynthesis, and consequently, the excess electrons are diverted to the production of ROS. Therefore, under conditions of water stress, the plant exhibits an increased demand for $\mathrm{K}$ to maintain photosynthesis and protect the chloroplasts from oxidative damage. This author also stresses the importance of $\mathrm{K}$ in the translocation of assimilates. Under $\mathrm{K}$ deprivation, there is reduced exportation of the products of photosynthesis to the drain region of the plant. Thus, the accumulation of photoassimilates in the chloroplast can decrease the fixation of $\mathrm{CO}_{2}$ through down-regulation, thus increasing the generation of ROS.

According to Prado (2008), K promotes maintenance of the turgor of guard cells, allowing better opening and closing dynamics of the stomatal pores. Sangakkara et al. (2000) evaluated the effect of moisture and $\mathrm{K}$ fertilization on the physiology of two common bean cultivars and observed that the addition of $\mathrm{K}$ to the system via a nutrient solution promoted an increased photosynthetic rate under conditions of water stress in both cultivars. Catuchi et al. (2012) evaluated the net $\mathrm{CO}_{2}$ assimilation rate (A) in two soybean cultivars under water deficit conditions as well as 12 hours after rehydration and following supplementation with 0,90 and $180 \mathrm{mg} \mathrm{dm}^{-3} \mathrm{~K}$. The authors concluded that in general, the A values (Figure 3) in both cultivars decreased by $50 \%$ under water deficit, irrespective of the $\mathrm{K}$ level. In contrast, after rehydration, the cultivar BR 16 showed A values that were $27 \%$ higher in plants without the addition of $\mathrm{K}$ and $42 \%$ higher in plants supplied with $90 \mathrm{mg} \mathrm{dm}^{-3} \mathrm{~K}$ compared to the values in plants under drought. However, the higher dose of $\mathrm{K}$ did not allow the recovery of A after rehydration. Moreover, Embrapa 48 responded positively to supplementation with two doses of $\mathrm{K}$ in terms of the recovery of A. While in plants without added $\mathrm{K}$, there was no recovery of A observed. Plants that received doses of 90 and $180 \mathrm{mg} \mathrm{dm}^{-3} \mathrm{~K}$ showed $\mathrm{A}$ values that were 57 and $38 \%$ higher, respectively, than those in plants under water stress. These responses indicate that $\mathrm{K}$ may promote greater recovery of photosynthesis in soybean after a period of water restriction. According to Flexas et al. (2004), the intensity and duration of water restriction are key factors that define the speed and rate of recovery of plants after rehydration. In general, plants subjected to severe drought stress exhibit recovery of only $40-60 \%$ of the maximum photosynthetic rate on the next day. In a study performed by Catuchi et al. (2012), these values were only achieved in plants that were supplemented with $\mathrm{K}$. The response of the recovery of plants supplied with $\mathrm{K}$ via fertilization may be related to the influence of this nutrient on the repair of oxidative damage to cells under 
conditions of water stress (Soleimanzadeh et al., 2010). The higher photosynthetic rates of plants supplied with $\mathrm{K}$ after recovery could provide greater restoration of plant growth, minimizing productivity losses.

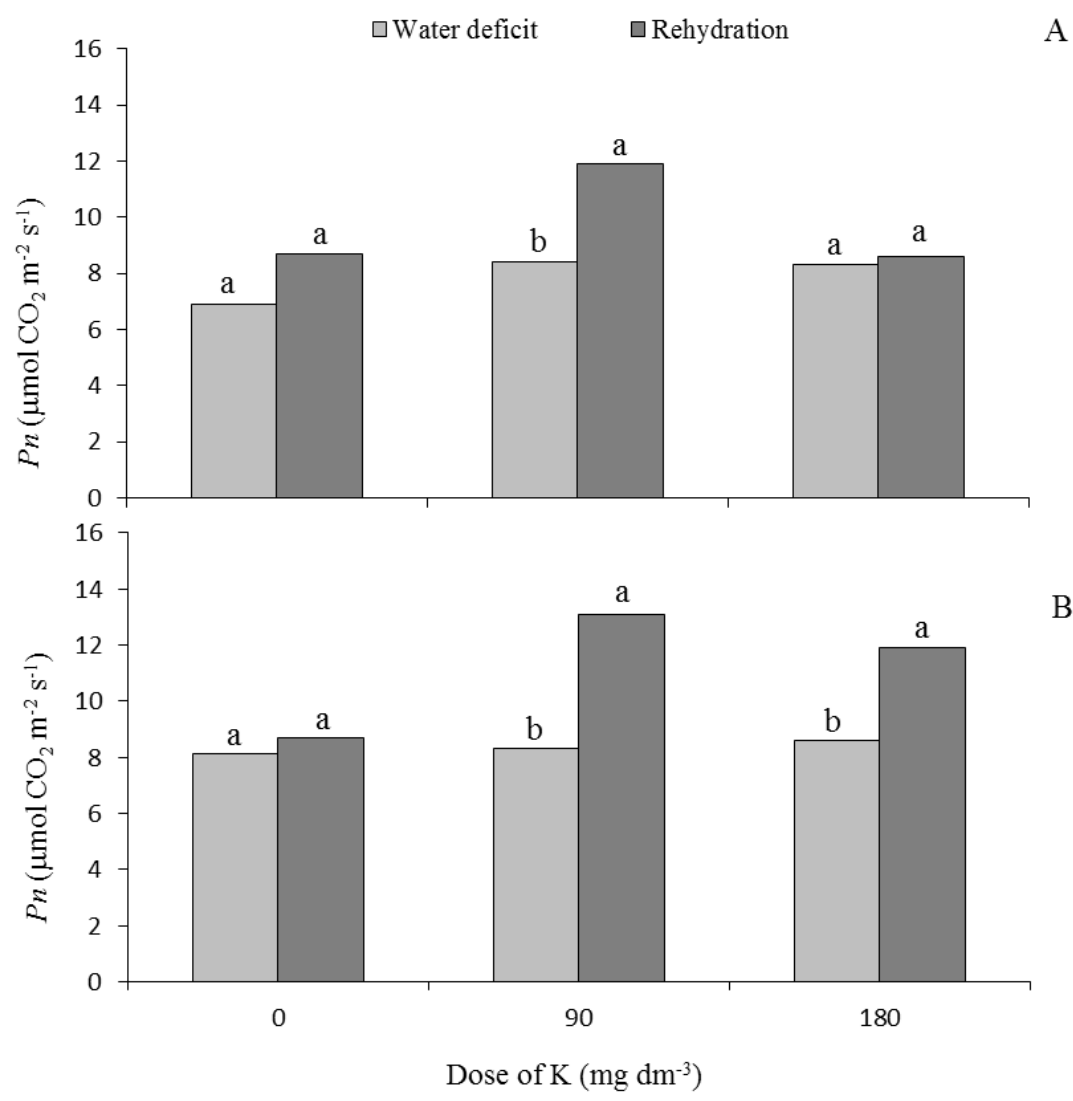

Figure 3. Average of net photosynthesis (Pn) of cultivars BR-16 (A) and Embrapa $48(\mathrm{~B})$ grown under water stress $(40 \%)$ and 12 hours after rehydration. The letters above the bars indicate the statistical difference $(p<0,005)$ between the water levels in each dose of potassium (adapted from Catuchi et al, 2012).

\subsection{Effects of phosphorus}

Because of its role in the formation of adenosine triphosphate (ATP), phosphorus (P) plays key roles in the production of energy necessary for photosynthesis, the translocation of assimilates and many other metabolic processes. In its inorganic form, $\mathrm{P}$ is the substrate or end product in many enzymatic reactions, including photosynthesis and carbohydrate metabo- 
lism, and it is essential for the regulation of metabolic pathways in the cytoplasm and chloroplast, sucrose and starch synthesis, triose phosphate transport, translocation of sucrose and hexose synthesis (Araújo \& Machado, 2006).

According to Lantmann \& Castro (2004), for each ton of soybeans produced, the plant consumes $15 \mathrm{~kg}$ of $\mathrm{P}_{2} \mathrm{O}_{5}$ on average. Under conditions of low soil water availability, there is a marked reduction in P uptake by plants (Santos et al., 2006). When there is a lack of inorganic P (Pi) in the chloroplast, decreases in the production of ATP and NADPH may occur, resulting in a decrease in the regeneration of ribulose-1,5-biphosphate, which is crucial in the photosynthetic assimilation of $\mathrm{CO}_{2}$ (Lawlor \& Cornic, 2002).

The decrease in ATP synthesis in the chloroplast may be caused by low availability of free cytoplasmic Pi, which is exchanged for triose phosphate in the chloroplast by phosphate transporters that use $\mathrm{Pi}$ as a substrate (Flügge et al., 2003). The carbon partitioning between starch and sucrose is dependent on the concentration of cytoplasmic Pi, which regulates the export of triose-P from the chloroplast to the cytosol, and a decrease in the recycling of $\mathrm{P}$ between the cytoplasm and chloroplasts can generate inhibition of photosynthesis via carbohydrate accumulation (Foyer, 1988). During drought periods lasting approximately ten days, the diffusive flux of $\mathrm{P}$ from the soil to plants stops almost completely, causing a significant loss of productivity (Novais \& Smyth, 1999). Thus, there is a need for a stock of P under optimal conditions of water availability to reduce the effects of the lack of $\mathrm{P}$ during water stress (Prado, 2008). Furthermore, after rehydration, the absorption and uptake of $\mathrm{P}$ should begin rapidly to restore the diffusion flow.

The direct role of $\mathrm{P}$ in the maintenance of plant productivity under low water availability is also related to the maintenance of stomatal conductance (Waraich et al., 2011). This function of $\mathrm{P}$ is associated with the osmotic regulation of stomatal guard cells because $\mathrm{P}$ supplementation can be related to the accumulation of proline, which is an important regulator of cell osmolarity (Al-Karaki et al., 1996). Firmano et al. (2009) evaluated the effects of P on photosynthesis in soybean plants grown under a water deficit and observed (Figure 4) that fertilization with $200 \mathrm{~kg} \mathrm{ha}^{-1} \mathrm{P}$ maintained net photosynthesis under water stress better in comparison to what was observed in plants that were not supplemented. According to these authors, these results were due to increased stomatal conductance promoted by $\mathrm{P}$ under conditions of water restriction.

Santos et al. (2006) evaluated the effect of foliar supplementation with inorganic phosphate (Pi) in two common bean genotypes, A320 and Ouro Negro, under water deficit conditions for 7 days. They observed that the rates of net photosynthesis and stomatal conductance were not affected by supplementation of Pi during dehydration in either genotype. However, after rehydration, stomatal conductance and photosynthesis were increased associated with foliar Pi being supplied in relation to the plants without Pi supplementation. Likewise, as noted by Firmano et al. (2009) in soybean, the role of Pi in the regulation of photosynthesis recovery after a water deficit appears to be important in reducing the deleterious effects of a temporary lack of water. 


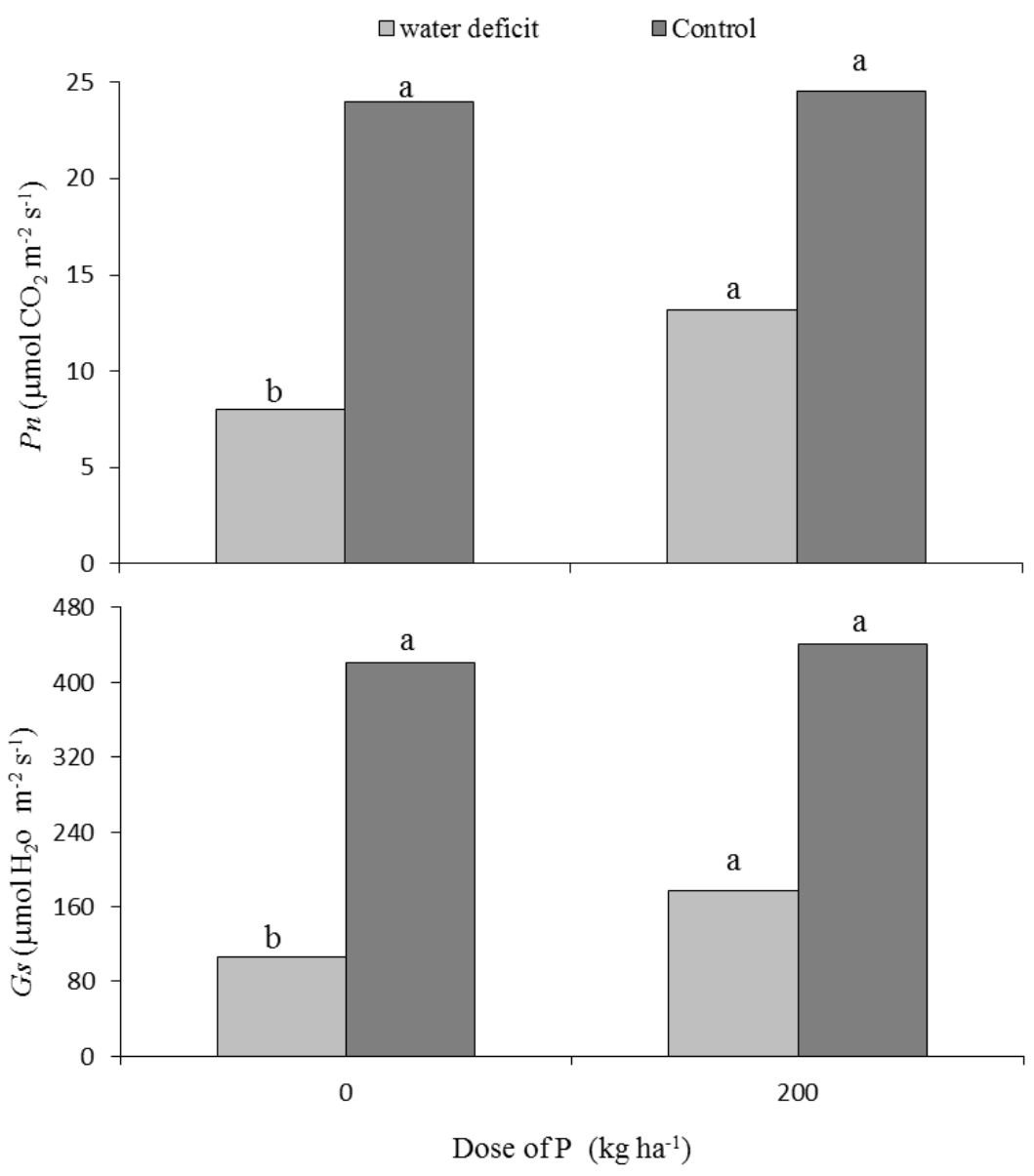

Figure 4. Average of net photosynthesis (Pn) and stomatal conductance (Gs) of soybean plants grown with and without water restriction. The lowercase letters above the bars indicates the statistical difference $(p<0,05)$ between the $P$ doses in each water level (adapted from Firmano et al, 2009).

\subsection{Effects of calcium}

The main functions of Ca in plants are acting as a component of the cell wall and as a second messenger in signaling associated with different processes in the cell. This nutrient plays an important role in ion uptake, root development and the germination of pollen grains (Vitti et al., 2006). During stress, Ca plays an important role in the regulation of plant metabolism, along with the calmodulin protein, which can promote the maintenance of cellular metabolism under water deficit conditions (Waraich et al, 2011). Ca assists the plant in its recovery after a water shortage because this nutrient functions in the activation of the ATPase en- 
zyme in the cell membrane, promoting the pumping back to the cell of electrolytes that were lost because of membrane damage caused by water deficit (Palta, 1990, Waraich et al., 2011).

In addition to the direct effects of $\mathrm{K}, \mathrm{P}$, and $\mathrm{Ca}$ on the maintenance of plant metabolism under water deficit conditions, balanced nutrition regarding all essential elements (both macro- and micronutrients) can support plant development under limiting conditions by improving the initial steps of vegetative growth, such as leaf area expansion. This improved growth will allow the achievement of high photosynthetic rates and, hence, good root development, thereby improving the absorption of water into deeper layers and allowing the plants to survive water deficit periods.

\subsection{Future directions}

Breeders and geneticists involved in soybean breeding are interested in consolidating the current knowledge about physiology and functional genomics to improve crop breeding programs (Manavalan et al., 2009), especially based on studies aimed at providing the information needed to improve the resistance / tolerance of cultivars to a multitude of stress factors (Kulcheski et al., 2011, Makbul et al., 2011). Through proteomic analysis, 145 genes that are differentially expressed according to the imposition of water stress were identified in two soybean cultivars, MG/BR46 [Conquista] and BR 16, that are considered tolerant and sensitive to water deficits, respectively (Stolf-Moreira et al., 2011). These genes were classified into nine functional categories: energy, transcription factors, metabolism, stress responses, protein synthesis, cell communication, the cell cycle, cellular transport, and other unknown functions. Additionally, 11 micro-RNAs that show different expression patterns during the imposition of biotic and abiotic stress were identified in the cultivars 'Embrapa 48' (tolerant to drought stress) and 'BR 16' (sensitive to water stress) (Kulcheski et al., 2011), and the transcription of several other proteins related to oxidative damage, isoflavonoids and lignin synthesis was detected in soybean under water stress (Yamaguchi et al., 2010). Furthermore, Alam et al. (2010) reported that there are two enzymes involved in carbohydrate metabolism (UDP-glucose pyrophosphorylase and 2.3-biphosphoglycerate independent phosphoglyceratemutase) that are suppressed after exposure to a water deficit. The levels of these enzymes tended to revert to the basal level after rehydration of the plants, suggesting that the change in the allocation of carbon in soybean plants under drought may indicate an adaptive response. According to the authors of this report, the metabolism of carbohydrates is one of the processes that are most susceptible to water stress, after photosynthesis. Other studies have identified several soybean wildtypes that can be specifically adapted to adverse conditions, such as wind, water logging, salinity and water deficits, and may be useful for identifying genes related to tolerance / resistance to a variety of biotic and abiotic stresses (Lee et al., 2010). Such studies are required because genetic diversity has been lost in the process of domestication of G. max (Hyten et al., 2006), and wildtype soybean have been useful for contributing new and unique genes to increase yields under different worldwide crop conditions (Wang et al., 2004).

Moreover, as discussed in previous sections of this chapter, to improve soybean growth under water deficit conditions, the application of additional strategies is necessary, such as 
constant development of new soil management techniques, allowing the development of root systems to increase the water intake capacity as well as provide balanced nutrition to the crop, supporting adequate development of the plants throughout their life cycle.

\section{Author details}

Gustavo M. Souza ${ }^{1}$, Tiago A. Catuchi ${ }^{2}$, Suzana C. Bertolli ${ }^{1}$ and Rogerio P. Soratto ${ }^{2}$

1 Laboratório de Ecofisiologia Vegetal, Universidade do Oeste Paulista, Presidente Prudente, SP, Brazil

2 Departamento de Produção Vegetal, Faculdade de Ciências Agronômicas, Universidade Estadual Paulista, Botucatu, SP, Brazil

\section{References}

[1] Aasamaa, K., Sõber, A. (2011). Responses of stomatal conductance to simultaneous changes in two environmental factors. Tree Physiology. v. 31, p. 855-864.

[2] Alam, I., Sharmin, S. A., Kim, K-H., Yang, J. K., Choi, M. S., Lee, B-H. (2010). Proteome analysis of soybean roots subjected to short-term drought stress. Plant Soil. v. 333, p. 491-505.

[3] Araújo, A. P. and Machado, C. T. T. (2006). Fósforo. In: Fernandes, M. S. Nutrição mineral de plantas. SBCS, p. 253-280.

[4] Al-Karaki, G. N., Clark, R. B. and Sullivan, C. Y. (1996). Phosphorus nutrition and water effects on proline accumulation in sorghum and bean. Journal of Plant Physiology, Leipzig, Germany, v. 148, p. 745-751.

[5] Ape1, K, Hirt H. (2004). Reactive oxygen species: Metabolism,oxidative stress, and signal transduction. Ann Rev Plant Bio, v. 55, p. 373-399.

[6] Akýnci, S. \& Lösel, D. M. (2012). Plant Water-Stress Response Mechanisms. In:Rahman, I. M. M. and Hasegawa, H. Water Stress, InTech, Croatia, p. 15-42.

[7] Baker, N. R., Rosenqvist, E. (2004). Applications of chlorophyll fluorescence can improve crop production strategies: an examination of future possibilities. Journal of Experimental Botany. v. 55, p. 1607-1621.

[8] Beutler, A. N. \& Centurion, J. F. (2003). Efeito do conteúdo de água e da compactação do solo na produção de soja. Pesq. agropec. bras., v. 38, n. 7, p. 849-856.

[9] Beutler, N. A., Centurion, J. F. Centurion, M. A. P. C. \& da Silva, A. P. (2006). Efeito da compactação na produtividade de cultivares de soja em latossolo vermelho. $R$. Bras. Ci. Solo, v. 30, p. 787-794. 
[10] Bertolli, S. C., Rapchan, G. L., Souza, G. M. (2012). Photosynthetic limitations caused by different rates of water-deficit induction in Glycine max and Vignaunguiculata. Photosynthetica. DOI: 10. 1007/s11099-012-0036-4.

[11] Braida, J. A., Bayer, C., Albuquerque, J. A. \& Reichert, J. M. (2011). Matéria Orgânica e seu Efeito na Física do Solo. In:Klauberg Filho, O., Mafra, A. L. andGatiboni, L. C. Tópicos em Ciência do Solo. SBCS, v. 7, p. 221-278.

[12] Brown, E. A., Caviness, C. E., Brown, D. A. (1985). Response of selected soybean cultivars to soil moisture deficit. Agron. J., v. 77, pp. 274-278.

[13] Bunce, J. A. (1977). Leaf elongation in relation to leaf water potential in soybean. Exp. Bot., v. 28, pp. 158-63.

[14] Cakmak, I. (2005). The role of potassium in alleviating detrimental effects of abiotic stresses in plants. J. Plant Nutr. Soil Sci. Turquia, v. 168, p. 521-530.

[15] Câmara, G. M. S. \& Heiffig, L. S. (2000). Fisiologia, ambiente e rendimento da cultura da soja. In: Câmara, G. M. S. Soja: tecnologia da produção. Piracicaba: ESALQ/LPV, p. $81-120$.

[16] Casagrande, E. C., Farias, J. R. B., Neumaier, N., Oya, T., Pedroso, J., Martins, P. K., Breton, M. C. \& Nepomuceno, A. L. (2001). Expressão gênica diferencial durante déficit hídrico em soja. R. Bras. Fisiol. Veg. v. 13, n. 2, p. 168-184.

[17] Catuchi, T. A., Guidorizzi, F. V. C., Guidorizi, K. A., Barbosa, A. M. \& Souza, G. M. (2012). Respostas fisiológicas de cultivares de soja à adubação potássica sob diferentes regimes hídricos. Pesq. agropec. bras., v. 47, n. 4, p. 519-527.

[18] Catuchi, T. A., Vítolo, H. F., Bertolli, S. S. \& Souza, G. M. (2011). Tolerance to water deficiency between two soybean cultivars: transgenic versus conventional. Ciência Rural, Santa Maria, v. 31, n. 3, p. 373-378.

[19] Cardoso, E. C., Zotarelli, L., Piccinin, J. L., Torres, E., Odilon Ferreira Saraiva, O. F. \& Guimarães, M. F. (2006). Sistema radicular da soja em função da compactação do solo no sistema de plantio direto. Pesq. agropec. bras., v. 41, n. 3, p. 493-501.

[20] Carmo-Silva, A. E., Keys, A. J., Andralojc, P. J., Powers, S. J., Arrabaça, M. C., Parry, M. A. J. (2010). Rubisco activities, properties, and regulation in three different $C 4$ grasses under drought. Journal of Experiemental Botany. v. 61, p. 2355-2366.

[21] Chaves, M. M., Flexas, J., Pinheiro, C. (2009). Photosynthesis under drought and salt stress: regulation mechanisms from whole plant to cell. Annals of Botany. v. 103, p. $551-560$.

[22] Confalone, A. \& Navarro Dujmovich, M. (1999). Influência do "déficit" hídrico sobre a eficiência da radiação solar em soja. Rev. Bras. de Agrociência, v. 5, n. 3, p. 195-198.

[23] Dechen, A. R. \& Nachtigall, G. R. (2006). Elementos essências e benéficos às plantas superiores. In:Fernandes, M. S. Nutrição mineral de plantas. SBCS, p. 01-06. 
[24] Demmig-Adams, B., Adams, Iii W. W., Mattoo A. (2006). Photoprotection, photoinhibition, gene regulation and environment. In: Advances in photosynthesis and respiration. v. 21. Dordrecht: Springer. eds.

[25] Desclaux, D., Huynh, T. \& Roumet, P. (2000). Identification of soybean plant characteristics that indicate the timing of drought stress. Crop Science. v. 40, p. 716-722.

[26] Desclaux, D., Roumet, P. (1996). Impact of drought stress on the phenology of two soybean (Glycine max L. Merr) cultivars. Field Crops Research. v. 46, p. 61-70.

[27] Doss, B. D. \& Thulow, D. L. (1974). Irrigation, row width and plant population in relation to growth characteristics of two soybean varieties. Agronomy Journal, Madison, v. 65. p. 620-623.

[28] Eck, H. V., Mathers, A. C. \& Musick, J. T. (1987). Plant water stress at various growth stages and growth and yield of soybeans. Field Crops Res., v. 17, pp. 1-16.

[29] Embrapa. (2011). Sistema de Produção 15. Exigências Climáticas. In: Tecnologia de produção de soja - Região central do Brasil - 2012 e 2013. Londrina: Embrapa Soja, p. 11-12. $<$ http://www. cnpso. embrapa. br/download/SP15-VE. pdf $>$. [Accessed on 09/06/2012].

[30] FAOSTAT - Food And Agriculture Organization Of The United Nations (2012). Production - crops. Roma, Food And Agriculture Organization Of The United Nations. Disponível em: < http://faostat. fao. org/site/567/default. aspx\#ancor >. [Accessed on 05/06/2012].

[31] Farias, J. R. B, Nepomuceno, A. L. \& Neumaier, N. (2007). Ecofisiologia da soja. Londrina: EMBRAPA-CNPSo, 9 p. (EMBRAPA-CNPSo. Circular técnica, 48).

[32] Firmano, R. S Kuwahara, F. A. \& Souza, G. M. (2009). Relação entre adubação fosfatada e deficiência hídrica em soja. Ciência Rural,v. 39, n. 7, p. 1967-1973.

[33] Flexas, J., Barón, M., Bota, J., Ducruet, J., Gallé, A., Galmés, J., Jiménez, M., Pou, A., Ribas-Carbó, M., Sajnani, C., Tomás, M., Medrano, H. (2009). Photosynthesis limitations during water stress acclimation and recovery in the drought-adapted Vitis hybrid Richter-110 (V. berlandieri x V. rupestris). Journal of Experimental Botany. v. 60, p. 2362-2377.

[34] Flexas, J., Ribas-Carbó, M. Bota, J., Galmés, J., Henkle, M., Martínez-Cañellas, S., Medrano, H. (2006a). Decrease Rubisco activity during water stress is not induced by decreased relative water content but related to conditions of low stomatal conductance and chloroplast CO2 concentration. New Phytologist. v. 172, p. 73-82.

[35] Flexas, J., Bota, J., Galmés, J., Medrano, H., Ribas-Carbó. (2006b). Keeping a positive carbon balance under adverse conditions: responses of photosynthesis and respiration to water stress. PhysiologiaPlantarum. v. 127, p. 343-352. 
[36] Flexas, J., Bota, J., Loreto, F., Cornic, G. \& Sharkey, T. D. (2004). Diffusive and metabolic limitations to photosynthesis under drought and salinity in C3 plants. Plant Biology, v. 6, p. 269-279.

[37] Flügge, U. I., Häusler, R. E., Ludewig, F. \& Fischer, K. (2003). Functional genomics of phosphate antiport systems of plastids. PhysiologiaPlantarum, Hoboken, v. 118. p. 475-482.

[38] Foyer, C. H. (1988). Feedback inhibition of photosynthesis through source-sink regulation in leaves. Plant Physiology and Biochemistry, Paris, v. 26, p. 483-492.

[39] Franchini, J. C., Debiasi, H., Sacoman, A. Nepomuceno, A. L. \& Farias, J. R. B. (2009). Manejo do solo para redução das perdas de produtividade pela seca. In: EmbrapaCnpso, 39p. (Embrapa-Cnpso. Circular técnica, 314).

[40] Grassi, G., Magnani, F. (2005). Stomatal, mesophyll conductance and biochemical limitations to photosynthesis as affected by drought and leaf ontogeny in ash and oak trees. Plant, Cell and Environment. v. 28, p. 834-849.

[41] Gerten, D. \& Rost, S. (2010). Development and Climate Change: Climate change impacts on agricultural water stress and impact mitigation potential. Potsdam Institute for Climate Impact Research (PIK), Germany, 8p.

[42] Hyten, D., Song, Q., Zhu, Y., Choi, I. Y., Nelson, R. L., Costa, J. M., Specht, J. E., Shoemaker, R. C., Cregan, P. B. (2006). Impacts of genetic bottlenecks on soybean genome diversity. Proceedings of the National Academy of Sciences. v. 103, p. 16666-16671.

[43] Gopefert, H., Rossetti, L. A., Souza, J. (1993). Eventos generalizados e seguridade agrícola. Brasília: IPEA, Ministério do Planejamento, 78p.

[44] Hoogenboom, G, Peterson, C. M., Huck, M. G. (1987). Shoot growth rate of soybean as affected by drought stress. Agron. J., v. 79, pp. 598-607.

[45] Jaleel, C. A., Manivannan, P., Wahid, A., Farooq, M., Al-Juburi, H. J., Somasundaram, R., Panneerselvam, R. (2009). Drought stress in plants: a review on morphological characteristics and pigments composition. International journal of agriculture $\mathcal{E}$ biology. v. 11, p. 100-105.

[46] Kaiser, W. M. (1987). Effects of water deficit on photosynthetic capacity. PhysiologiaPlantarum. Copenhagen, v. 71, p. 142-149.

[47] Kao, W. -Y, Tsai, T. -T. (1998). Tropic leaf movements, phosynthetic gas exchange, leaf $\delta^{13} \mathrm{C}$ and chlorophyll a fluorescence of three soybean species in response to water availability. Plant, Cell and Environment. v. 21, p. 1055-1062.

[48] Kawaguchi, R., Williams A. J., Bray, E. A., Bailey-Serres, J. (2003). Water-deficit-induced translational control in Nicotianatabacum. Plant, Cell and Environment. v. 26, p. 221-229.

[49] King, C. A. \& Purcell, L. C. (2001). Soybean Nodule Size and Relationship to Nitrogen Fixation Response to Water Deficit. Crop Science, v. 41, p. 1099 - 1107. 
[50] Kirova, E., Tzvetkova, N., Vaseva, I., Ignatov, G. (2008). Photosynthetic Responses of Nitrate-Fed and Nitrogen-Fixing soybeans to progressive water stress. Journal of Plant Nutrition. v. 31, p. 445-458.

[51] Kumar, A., Li, C., Portis A. R. Jr. (2009). Arabidopsis thaliana expressing a thermostable chimeric Rubisco activase exhibits enhanced growth and higher rates of photosynthesis at moderately high temperatures. Photosynth Res. v. 100, p. 143-153.

[52] Kulcheski, F. R., Oliveira, L. F. V., Molina, L., Almerão, M. P., et al. (2011). Identification of novel soybean microRNAs invoved in abiotic and biotic stresses. BMC Genomics. v. 12 , p. 307.

[53] Kron, A. P., Souza, G. M. \& Ribeiro, R. V. (2008). Water deficiency at different developmental stages of Glycine max can improve drought tolerance. Bragantia, v. 67, n. 1, p. $43-49$.

[54] Kumudini, S. (2010). Soybean Growth \& Development. In: B Singh, (Ed. ). The Soybean: Botany, Production and Uses. CAB International, Oxfordshire, UK, p. 48-73.

[55] Lantmann, A. F. \& Castro, C. (2004). Resposta da soja à adubação fosfatada. In: Yamada, T. \& Abdalla, S. R. S. Fósforo na agricultura brasileira, p. 223-239.

[56] Larcher, W. (2000). Ecofisiologia Vegetal. Traduzido por PRADO, C. H. B. A. RiMa Artes e textos, São Carlos. p. 531.

[57] Lawlor, D. W. \& Cornic, G. (2002). Photosynthetic carbon assimilation and associated metabolism in relation to water deficits in higher plants. Plant, Cell and Environment, v. 25. p. 275-294.

[58] Lawlor, D. W., Tezara, W. (2009). Causes of decreased photosynthetic rate and metabolic capacity in water-deficient leaf cells: a critical evaluation of mechanisms and integration of processes. Annals of Botany. v. 103, p. 561-579.

[59] Lee, J. -D., Shannon J. G., Vuong, T. D., Moon, H., Nguyen, H. T., Tsukamoto, C., Chung, G. (2010). Genetic diversity in wild soybean (Glycine sojaSieb. and Zucc. ) accessions from southern island of Korean peninsula. Plant Breeding. v. 129, p. 257-263.

[60] Li-Juan, Q. \& Ru-Zhen, C. (2010). The Origin and History of Soybean. In: B Singh, (Ed. ). The Soybean: Botany, Production and Uses. CAB International, Oxfordshire, UK, p. 01-23.

[61] Lisar, S. Y. S., Motafakkerazad, R., Hossain, M. M. \& Rahman, I. M. M. (2012). Water Stress in Plants: Causes, Effects and Responses. In:Rahman, I. M. M. \& Hasegawa, H. Water Stress, InTech, Croatia, p. 01-14.

[62] Machado, P. L. O. A. (1997). Considerações gerais sobre a toxicidade do alumínio nas plantas. EMBRAPA-CNPS, 22p. (EMBRAPA-CNPS. Documentos , 2).

[63] Majumdar, S., Ghosh, S., Glick, B. R., Dumbroff, E. B. (1991). Activities of chlorophyllase, phosphoenolpyruvate carboxylase and ribulose-1,5-bisphosphate carboxylase in 
the primary leaves of soybean during senescence and drought. PhysiologiaPlantarum. v. 81 , p. $473-480$.

[64] Makbul, S., SaruhanGüler, N., Durmus, N., Güven, S. (2011). Changes in anatomical and physiological parameters of soybean under drought stress. Turk J. Bot. v. 35, p. 369-377.

[65] Malavolta, E. Função dos Macros e Micronutrientes: Manual de Nutrição Mineral de Plantas. São Paulo. Editora Agronômica Ceres, 2006. 638p.

[66] Manavalan, L. P., Guttikonda, S. K., Tran, L-S. P., Nguyen, H. (2009). Physiological and molecular approaches to improve drought resistance in soybean. Plant and Cell Physiology. v. 50, p. 1260-1276.

[67] Mascarenhas, H. A. A., Camargo, C. E. de O. \& Falivene, S. M. P. (1984). Efeito do alumínio sobre o crescimento de raízes, peso seco da parte aérea e raízes de diferentes cultivares de soja. Bragantia, v. 43, n. 1, p. 191-200.

[68] Mascarenhas, H. A. A., Tanaka,R. T., Wutke, E. B., Braga, N. R., Miranda. M. A. C. (2004). Potássio para a soja. Informações Agronômicas №105, 2p.

[69] Miyake, C. (2010). Alternative electron flow (water-water cycle and cyclic electron flow around PSI) in photosynthesis: molecular mechanisms and physiological function. Plant and Cell Physiology. v. 51, p. 1951-1963.

[70] Miyake, C., Amako, K., Shiraishi, N., Sugimoto, T. (2009). Acclimation of tobacco leaves to high light intensity drives the plastoquinone oxidation system - relationship among the fraction of open PSII centers, non-photochemical quenching of chl fluorescence and the maximum quantum yield off PSII in the dark. Plant and Cell Physiology. v. 50, p. 730-743.

[71] Mott, K A., Buckley, T. N. (1998). Stomatal heterogeneity. Journal of Experimental Botany. v. 49, p. 407-417.

[72] Muchow, R. C., Sinclair, T. R., Bennett, J. M. \& Hammond, L. C. (1986). Response of leaf growth, leaf nitrogen, and stomatal conductance to water deficits during vegetative growth of field-grown soybean. Crop Sci., v. 26, pp. 1190-1195.

[73] Mundstock, C. M. \& Thomas, A. L. (2005). Soja: fatores que afetam o crescimento e rendimento de grãos. Porto Alegre: Universidade Federal do Rio Grande do Sul, 31 p.

[74] Mutei, H. (2011). Papel do Brasil no combate a fome no mundo. In: Siqueira, F., Caju, J. \& Moreira, M. Boletim de pesquisa da soja. Fundação MT, Mato Grosso, Brazil, n. 15, p. $45-48$.

[75] Nepomuceno, A. L., Farias, J. R. B., Neumaier, N. (1994). Efeitos da disponibilidade hídrica no solo sobre a cultura da soja. In: EMBRAPA-CNPSo, Ata - Documentos 72. Reunião de Pesquisa de Soja da Região Central do Brasil. Londrina, PR, v. 15, p. 42-43.

[76] Neumaier, N., Nepomuceno, A. L., Farias, J. R. B. (2000). Estresses de ordem ecofisiológica. In: Bonato, E. R. (ed. ). Estresses em soja. Passo Fundo: EMBRAPA Trigo, 254p. 
[77] Nepomuceno, A. L., Neumaier, N., Farias, J. R. B., Oya, T. (2001). Tolerância à seca em plantas. Biotecnologia Ciência e Desenvolvimento. v. 23, p. 12-18.

[78] Nogueira, S. S. S. \& Nagai, V. (1988). Deficiência hídrica simulada nos diferentes nos diferentes estádios de desenvolvimento de uma cultura precoce de soja. Bragantia. v. 47, n. 1, p. 9-14.

[79] Nolla, A., Schlindwein, J. A. \& Anghinoni, I. (2007). Crescimento, morfologia radicular e liberação de compostos orgânicos por plântulas de soja em função da atividade de alumínio na solução do solo de campo natural. Ciência Rural,v. 37, n. 1, p. 97-101.

[80] Novais, R. F., Smyth, T. T. (1999). Fósforo em solo e planta em condições tropicais. Viçosa: Universidade Federal de Viçosa, 399p.

[81] Ohashi, Y., Nakayama, N., Saneoka, H., Mohapatra, P. K., Fujita, K. (2009). Differences in the responses of stem diameter and pod thickness to drought stress during the grain filling stage in soybean plants. ActaPhysiol Plant. v. 31, p. 271-277.

[82] Ohashi, Y., Nakayama, N., Saneoka, H., Fujita, K. (2006). Effects of drought stress on photosynthetic gas exchange, chlorophyll fluorescence and stem diameter of soybean plants. Biologia Plantarum. v. 50, p. 138-141.

[83] Oliveira, A., Fernandes, E. J., Rodrigues, T. J. D. (2005). Condutância estomática como indicador de estresse hídrico em feijão. Eng. Agríc., Jaboticabal, v. 25, n. 1, p. 86-95.

[84] Palta, J. P. (1990). Stress Interactions at the Cellular \& Membrane Levels. Hort. Sci. v. 25, n. 11, p. 1377-1381.

[85] Pang, J., Yang, J., Ward P., Siddique K. H. M., Lambers, H., Tibbett, M., Ryan, M. (2011). Contrasting responses to drought stress in herbaceous perennial legumes. Plant Soil. v. 348, p. 299-314.

[86] Pankhurst, C. E. \& Sprent, J. I. (1975). Effects of water stress on respiratory and nitrogen-fixing activity of soybean root nodules. J. Exper. Bot., v. 26, pp. 287-304.

[87] Pankovic, D., Sakac, D., Kevresan, S., Plesnicar, M. (1999). Acclimation to long-term water deficit in the leaves of two sunflower hybrids: photosynthesis, electron transport and carbon metabolism. Journal of Experimental Botany. v. 50, p. 127-138.

[88] Parry, M. A. J., Andralojc, P. J., Khan, S., Lea, P., Keys, A. J. (2002). Rubisco activity: effects of drought stress. Annals of Botany. v. 89, p. 833-839.

[89] Pelloux, J., Jolivet, Y., Fontaine, V., Benvoy, J., Dizengremel, P. (2001). Changes in Rubisco and Rubisco activase gene expression and polypeptide content in Pinushalepensis M. subjected to ozone and drought. Plant, Cell and Environment. v. 24, p. 123-131.

[90] Pinheiro, C., Chaves, M. M. (2011). Photosynthesis and drought: can we make metabolic connections from available data? J. Experimental Botany. v. 62, p. 869-882. 
[91] Pitzschke, A., Forzani, C. \& Hirt, H. (2006). Reactive Oxygen Species Signaling in Plants. Antioxidants and Redox Signaling, v. 8, n. 9, p. 1757-1764.

[92] Prado, R. M. (2008). Nutrição de Plantas. (Ed. )., São Paulo. Unesp, 2008. p. 161-181.

[93] Purcell, L. C., King, C. A., Ball, R. A. (2000). Soybean Cultivar Differences in Ureides and the Relationship to Drought Tolerant Nitrogen Fixation and Manganese Nutrition. Crop Science, v. 40, v. 1062 - 1070.

[94] Purcell, L. C, Serraj, R., Sinclair, T. R., De, A. (2004). Soybean N2 Fixation Estimates, Ureide Concentration, and Yield Responses to Drought. Crop Science, v. 44, p. 484-492.

[95] Purcell, L. C. \& Specht, J. E. (2004). Physiological traits for ameliorating drought stress. In: Soybeans: improvement, production, and uses (third ed. ),Boerma, H. R., Specht, J. E. (Eds. ), pp. 569-620, American Society of Agronomy, Madison, WI.

[96] Raper, C. D. \& Kramer, P. J. (1987). Stress Physiology, In: Soybeans: Improvement, production, and uses, Wilcox, J. R. (Ed. )., pp. 589-641. American Society of Agronomy, Madison, WI.

[97] Reynolds-Henne, C. E., Langenegger, A., Mani, J., Schenk, N., Zumsteg, A., Feller, U. (2010). Interactions between temperature, drought and stomatal opening in legumes. Environmental and Experimental Botany. v. 68, p. 34-43.

[98] Rosolem, C. A. (2005). Papel do Brasil no combate a fome no mundo. In: Suzuki, S., Yuyama, M. M. \& Camacho, S. A. Boletim de pesquisa da soja. Fundação MT, Mato Grosso, Brazil, n. 09, p. 95-102.

[99] Rossatto, D. R., Hoffmann, W. A., Franco, A. C. (2009). Differences in growth patterns between co-occurring forest an savanna trees affect the forest-savanna boundary. Functional Ecology. v. 23, p. 689-698.

[100] Sanda, S., Yoshida, K., Masayoshi, K., Kawamura, T., Munekage, Y. N., Akashi, K., Yokota, A. (2011). Responses of the photosynthetic electron transport system to excess light energy caused by water deficit in wild watermelon. PhysiologiaPlantarum. 142: 247-264.

[101] Sangakkara, U. R., Frehner, M. \& Nösberger, J. (2000). Effect of Soil Moisture and Potassium Fertilizer on Shoot Water Potential, Photosynthesis and Partitioning of Carbon in Mungbean and Cowpea. J. Agronomy e Crop Science. v. 185, p. 201-207.

[102] Santos M. G., Ribeiro, R. V., Oliveira, R. F., Machado, E. C. \& Pimentel, C. (2006). The role of inorganic phosphate on photosynthesis recovery of commom bean after a mild water deficit. Plant Science, v. 170, p. 659-664.

[103] Santos, R. F., Carlesso, R. (1988) Déficit hídrico e os processos morfológicos e fisiológicos das plantas. R. Bras. Eng. Agríc. Ambiental, v. 2, n. 3, p. 287-294, 1998. 
[104] Santos, A. C., Vilela, L. C. Barreto, P. M., Castro, G. J. D. \& J. E C. Silva. (2010). Alterações de atributos químicos pela calagem e gessagem superficial com o tempo de incubação. Revista Caatinga, v. 23, n. 1, p. 77-83.

[105] Sarlikioti, V., Driever, S. M., Marcelis, L. F. M. (1993). Photochemical reflectance index as a mean of monitoring early water stress. Annals of Applied Biology. 157: 81-89. 2010 .

[106] Singh, G. \& Shivakumar, B. G. (2010) The role of soybean in agriculture. In: B Singh, (Ed. ). The Soybean: Botany, Production and Uses. CAB International, Oxfordshire, UK, pp. 24-47.

[107] Smirnoff, N. (1993) The role of active oxygen in the response of plants to water deficit and desiccation. New Phytol. v. 125, p. 27-58.

[108] Soleimanzadeh, H., Habibi, D., Ardakani, M. R., Paknejad, F. \& Rejali, F. (2010). Effect of Potassium Levels on Antioxidant Enzymes and Malondialdehyde Content under Drought Stress in Sunflower (Helianthus annuusL. ). American Journal of Agricultural and Biological Sciences, v. 5, n. 1, p. 56-61.

[109] Sprent, J. I. (1971). The effects of water stress on nitrogen-fixing root nodules. New Phytologist, v. 70, pp. 9-17.

[110] Stolf-Moreira, R., Lemos, E. G. M., Carareto-Alves, L, et al. (2011). Transcriptional profiles of roots of different soybean genotypes subjected to drought stress. Plant Mol. Biol. Rep. v. 29, p. 19-34.

[111] Taiz, L. \& Zeiger, E. (2009). Fisiologia vegetal. 4º ed. Artmed Editora, Porto Alegre, 848 p.

[112] Vitti, G. C., Lima, E. \& Cicarone, F. (2006). Cálcio, magnésio e nxofre. In: Fernandes, M. S. Nutrição mineral de plantas. SBCS, p. 299-326.

[113] Zhang, R., Sharkey, T. D. (2009). Photosynthetic electron transport and photon flux under moderate heat stress. Photosynth Res. v. 100, p. 29-43.

[114] Wang, D., Graef, G. L., Procopiuk, A. M., Diers, B. W. (2004). Identification of putative QTL that underline yield in interspecific soybean backcross populations. Theor. Appl. Genet. v. 108, p. 458-467.

[115] Waraich, E. A., Ahmad, R., Saifullah., Ashraf, M. Y., \& Ehsanullah. (2011). Role of mineral nutrition in alleviation of drought stress in plants. Australian Journal of Crop Science, v. 5, n. 6, p. 764-778.

[116] Yamaguchi, M., Valliyodan, B., Zhang, J., Lenoble, M. E., Yu, O., Rogers, E. R., Nguyen, H. T., Sharp, R. E. (2010). Regulation of growth response to water stress in the soybean primary root. I. Proteomic analysis reveals region-specific regulation of phenylpropanoid metabolism and control of free iron in the elongation zone. Plant, Cell and Environment. v. 33, p. 223-343. 
[117] Yu, G-R., Wang, Q-F., Zhuang, J. (2004). Modeling the water use efficiency of soybean and maize plants under environmental stress: application of a synthetic model of photosynthesis-transpiration based on stomatal behavior. J. Plant Physiol. v. 161, p. 303-318. 